\title{
Enhanced mechanical properties of a novel compatibilized recycled polyethylene terephthalate/polyamide 11 (rPET/PA11) blends
}

\author{
Z. I. Khan ${ }^{1}$, U. Habib ${ }^{1,2}$, Z. B. Mohamad ${ }^{1 *}$, A. M. Raji ${ }^{1}$ \\ ${ }^{1}$ Enhanced Polymer Research Group, School of Chemical \& Energy Engineering, Faculty of Engineering, Universiti \\ Teknologi Malaysia, 81310 Skudai, Johor, Malaysia \\ ${ }^{2}$ Chemical Department University of Engineering and Technology, Peshawar, Pakistan
}

Received 13 June 2021; accepted in revised form 3 August 2021

\begin{abstract}
This research investigates various proportions of a compatibilizer, Joncryl ${ }^{\circledR}$, in a newly developed blend of rPET/PA11 having $80 \mathrm{wt} \% \mathrm{rPET}$ and $20 \mathrm{wt} \%$ PA11. The proposed blend exhibits unique and outstanding mechanical properties. A few of the significant benefits of carrying out this research work include recycling the highest amount of rPET, saving natural recourses, and encountering the environmental issues associated with the wastage of polymers. Five different proportions of Joncryl ${ }^{\circledR}(0,1,2,3$ and $4 \mathrm{phr})$ were introduced to the blend of rPET/PA11 through a twin-screw extruder and injection moulding machine. The blend interface studied by scanning electron microscope (SEM) indicated that Joncryl ${ }^{\circledR}$ boosted the chain extension. The results of tensile strength, Young's modulus and flexural strength displayed the boost up in properties at all proportions; however, the properties at $2 \mathrm{phr}$ of Joncryl ${ }^{\circledR}$ were unique and exclusive. The tensile strength of blend at $2 \mathrm{phr}\left(\mathrm{Joncryl}^{\circledR}\right)$ is remarkably increased from 26.8 to $46.24 \mathrm{MPa}$ with a uniquely increased strain\% from 3.56 to $196 \%$. Young's modulus is also significantly improved. The impact strength rose from 147.12 to $667.68 \mathrm{~J} / \mathrm{m}$.
\end{abstract}

Keywords: recycling, thermoplastic blend, rPET, PA11

\section{Introduction}

Polymer blends have broadly been utilized as an essential strategy and affordable method to create new materials with explicit properties in late decades [13]. However, most polymers are immiscible because of their chemical structure difference, resulting in polymer blends with inferior properties than pure polymers, mainly mechanical properties. Therefore, to achieve the preferred property in non-miscible polymers, the addition of a compatibilizer is frequently required. The compatibilizer can go about as an interfacial agent to lessen the interfacial tension and upgrade interfacial bond adhesion between the polymers and, in this manner, improve the properties of the blends $[1,4]$.
Poly(ethylene terephthalate) (PET) is a superb engineering plastic and has broadly utilized in a variety of applications, such as bottles, films, packaging, etc. [5]. However, post-consumer PET is disposed of, causing environmental issues and a massive waste of valuable resources. Different strategies for reusing and recycling PET have been developed [6-9].

Among these techniques, mixing or blending rPET with different polymers is extremely attractive because of the blend of potential properties that would be unreachable in any single polymer and provide a market for the rPET. The study on rPET blended with high-density polyethylene/maleic anhydride polyethylene (HDPE/rPET/MAPE) was performed by Shahrajabian and Sadegihan [10]. The findings 
implied that the greatest tensile strength attained was $33.5 \mathrm{MPa}$ with a less than $5 \%$ strain, although it had alumina nanoparticles. The tensile strength stated in their work is not sufficient for various applications. Taghavi et al. [11] investigated the mechanical and thermal properties of the recycled PET in ternary blends PET/HDPE/MAPE and maleic anhydridegrafted styrene-ethylene/butylene-styrene PET/ HDPE/SEBS- $g$-MA. According to the results, the elongation at the breaking point of RPET was $4.4 \%$, but it increased by $20.296 \%$ for the ternary blend of RPET/ HDPE/SEBS- $g$-MA and $14.96 \%$ for the ternary blend of RPET/HDPE/MAPE. Avila and Duarte [12] blended rPET/HDPE and reported tensile strength up to $23 \mathrm{MPa}$. The Bio-PET/rPET was tested by Montava et al. [13] to extend rPET chains and assess compatibilizer polystyrene- $\mathrm{Co}$-glycidyl proportion methacrylate (PS-co-GMA). PET and polypropylene (PP) were discussed by many researchers [1417]. In addition, the investigation related to the effect of nanofillers on the matrix. rPET was blended with polyamide 6 (PA6) reported by several researchers $[1,4,18-20]$; however, the quantity of rPET utilized was less than $30 \mathrm{wt} \%$ and not analyzed systematically. The difficulties correlated with PA6 consist of high moisture sorption, low impact, hydrophilic in nature, and degradation of PA6, if kept for a prolonged time in a mass amount in an industry. In contrast to PA6, PA11 has low moisture sorption and does not degrade like PA6. PA11 presents high impact and excellent processability and is a bio-based material with exceptional mechanical and thermal properties $[21,22]$. Its matrix can accommodate many fillers and have an excellent tensile, impact, and thermal properties [22]. Accordingly, blending rPET with PA11 should be an easy and comparatively simple approach to acquire a promising material with better properties. Unfortunately, rPET/PA11 blends are immiscible, like PET/ PA6 blends obtained by a simple melt blending technique that reveals weaker mechanical properties than pure PET, PA6, or PA11 because of the weak compatibility between PET, PA6, and PA11 [1, 4, 23, 24].

Numerous studies were done to enhance PET/PA6 blends properties [25-27]. However, there is no data available on rPET/PA11/Joncryl ${ }^{\circledR}$ blends. In this research work, the novel blend of the rPET/PA11 was prepared and evaluated recently in our previous work, Khan et al. [24], to utilize the maximum percentage of rPET, i.e. $80 \mathrm{wt} \% \mathrm{rPET}$ and $20 \%$ PA11 recorded the best properties. The other article reported our earlier findings [24], the properties of the amorphous rPET/PA11 blend enhanced with the incorporation of $1 \mathrm{phr}$ Joncryl ${ }^{\circledR}$. This is the first time in literature, the newly formulated blend of rPET/PA11/Joncryl ${ }^{\circledR}$ blend at various compatibilizers content, introduced in this research to recycle $80 \mathrm{wt} \%$ of $\mathrm{rPET}$ with $20 \mathrm{wt} \%$ of PA1 1 and Joncry $\mathrm{l}^{\circledR}$ as a compatibilizer. In this study, the effect of different Joncry $1^{\circledR}$ ADR 4468 content on the mechanical properties of the blends was reported. The reaction and interaction of chain mechanisms for rPET/PA11, rPET/Joncryl ${ }^{\circledR}$ and PA11/Joncry $1^{\circledR}$ have been proposed. This research aimed to recycle the highest amount of rPET with improved mechanical properties. It saves valuable resources and encounters environmental problems associated with the wastage of non-biodegradable rPET going to the landfill sites.

\section{Experimental section}

\subsection{Materials and preparation of blends}

Postindustrial grade of rPET having intrinsic viscosity of $>0.68 \mathrm{dl} / \mathrm{g}$ (ASTM D4603-03), Ash content $<0.04 \%$ (ASTM D5630-05), crystallinity at least $25 \%$ (DSC) was bought from Alba Polyester. Sdn. Bhd Malaysia. PA11 brand Rilsan ${ }^{\circledR}$ BMN G8 TLDA (PA11, MHLRS, 12-010 CD) resin was purchased from Arkema, Pennsylvania, USA. Joncryl ${ }^{\circledR}$ ADR 4468 (TI/EV/BX 001 ) having a specific gravity of $1.08\left(25^{\circ} \mathrm{C}\right)$, the molecular weight of $7250, T_{\mathrm{g}}$ $\left(59^{\circ} \mathrm{C}\right)$, nonvolatile by $\mathrm{GC}[\%]>99$ and epoxy equivalent weight $[\mathrm{g} / \mathrm{mol}] 310$ was purchased from BASF corporation, Ludwigshafen Germany. The plan for preparing $\mathrm{rPET} / \mathrm{PA} 11 / \mathrm{Joncry} \mathrm{l}^{\circledR}$ blends is recapped in Figure 1. rPET/PA11 in the ratio of $80: 20 \mathrm{wt} \%$ with $0,1,2,3$, and 4 phr of Joncryl ${ }^{\circledR} 4468$ were assessed in the current research. First of all, rPET/PA11/Joncryl ${ }^{\circledR}$ materials were dried in an oven (Memmert, ULM 500, GEMINI LAB, DG Apeldoorn, The Netherlands) for 24 hours at $90^{\circ} \mathrm{C}$ to ensure humidity removal before the process. $\mathrm{PPET} / \mathrm{PA} 11 / \mathrm{Joncryl}^{\circledR}$ blends were formulated as mentioned in Table 1 via melt blending technique using twin co-rotation extruder (WERNER \& PFLEIDERER (ZSK25), Stuttgart, Federal Republic of Germany). The temperature profile was in the range of $240-300^{\circ} \mathrm{C}$ from the hopper to the die. Later on, the injection moulding machine (NI00B II, JSW (PTE) LTD, Japan) was applied for sample manufacturing according to the ASTM standard. Injection moulding machine temperature 


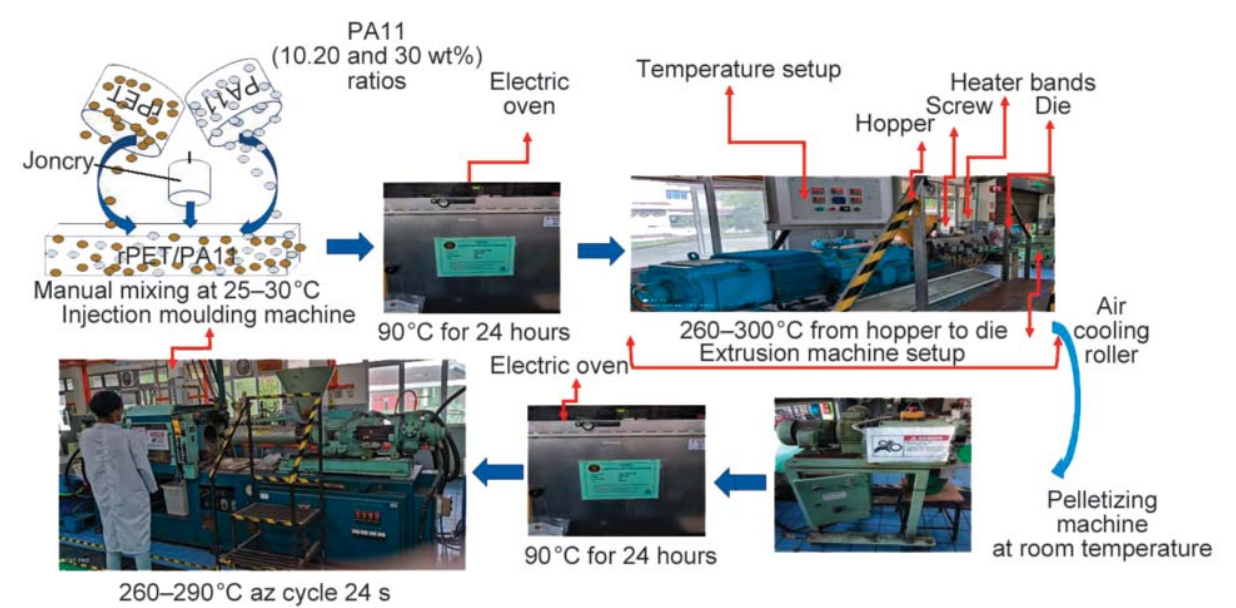

Figure 1. Preparation of rPET/PA11/Joncryl ${ }^{\circledR}$ blends.

Table 1. Formulation of rPET/PA11 and Joncryl ${ }^{\circledR}$ ADR 4468.

\begin{tabular}{|c|c|}
\hline $\begin{array}{c}\text { Formulation } \\
\text { [wt } \% \text { ] }\end{array}$ & Joncry $^{\circledR}$ ADR 4468 \\
\hline rPET/PA11:80/20 & 0 \\
\hline rPET/PA11:80/20 & 1 \\
\hline rPET/PA11:80/20 & 2 \\
\hline rPET/PA11:80/20 & 3 \\
\hline rPET/PA11:80/20 & 4 \\
\hline
\end{tabular}

was $260-290^{\circ} \mathrm{C}$ from the hopper to the die with an injection cycle of $24 \mathrm{~s}$.

\subsection{Characterization}

The tensile strength of all the blends was assessed according to the ASTM D638 standard. The tensile strength, flexural strength, percentage strain, and Young's modulus of rPET/PA11/Joncryl ${ }^{\circledR}$ blended specimens were determined using Zwick/Roell Z020 universal testing machine, made in Germany. The technical settings for the tensile testing with ASTM D638 were pre-load of $0.01 \mathrm{MPa}$, test speed $5 \mathrm{~mm} / \mathrm{min}$, elongation preset, secant modulus $1 \%$. Flexural testing was performed as per the ASTM D790 standard. The crosshead speed for flexural testing was $1 \mathrm{~mm} / \mathrm{min}$ with a pr-load of $0.1 \mathrm{MPa}$. The load cell of $20 \mathrm{kN}$ was utilized for both tensile and flexural testing. The sample dimensions for flexural strength were $127 \mathrm{~mm}$ length $\times 12.3 \mathrm{~mm}$ width $\times 5 \mathrm{~mm}$ thickness. Impact testing for all of the blends was performed through pendulum impact testing (Zwick Roell/HIT25P, Germany). The testing was done, agreeing to the Izod ASTM D256-10 standard. The capability of the machine was set to 11 Joules. All tests were done at room temperature. At least five repeats were tested for each formulation to report the tensile strength, flexural strength, and impact strength.
Scanning electron microscopy (SEM) was done through Hitachi TM3000, Japan. The magnification of $4000 \times$ was utilized with the size of $20 \mu \mathrm{m}$. Platinum coating for SEM was done through the Quorum sputter coater. The energy level, vacuum pressure, and current of $15 \mathrm{kV}, 2 \cdot 10^{-2} \mathrm{mbar}$, and $20 \mathrm{~mA}$ were set, respectively.

\section{Results and discussion}

\subsection{The effect of Joncryl ${ }^{\circledR}$ content on the interaction and structural confirmation of rPET/PA11 blends via FTIR}

Figure 2 shows the FTIR spectroscopy of rPET/PA11 blends having 0, 2, and 4 phr of Joncry ${ }^{\circledR}$ ADR 4468 along with pure ADR Joncryl ${ }^{\circledR}$. The absorbance peak at $3295.7 \mathrm{~cm}^{-1}$ confirmed $-\mathrm{NH},-\mathrm{NCH}, \mathrm{CH}$, and $\mathrm{OH}$ groups of rPET/PA11. The neat Joncryl ${ }^{\circledR}$ shown no peak at the same wavenumber. The less intense and broad peaks for rPET/PA11/Joncryl ${ }^{\circledR}$ spectra are observed compared with rPET/ PA11. rPET/PA11

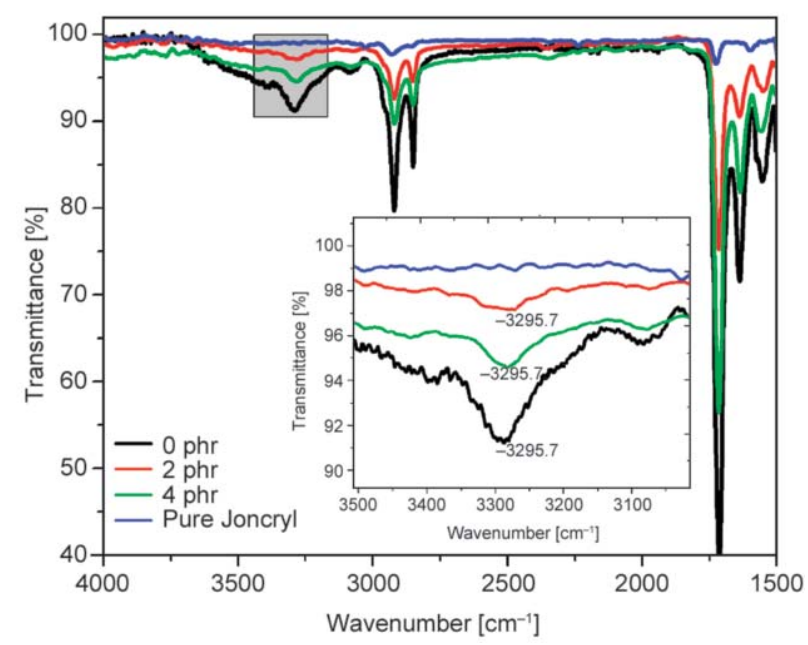

Figure 2. FTIR spectra of rPET/PA11 blends having 0, 2, 4 phr Joncryl ${ }^{\circledR}$ and pure Joncryl ${ }^{\circledR}$. 


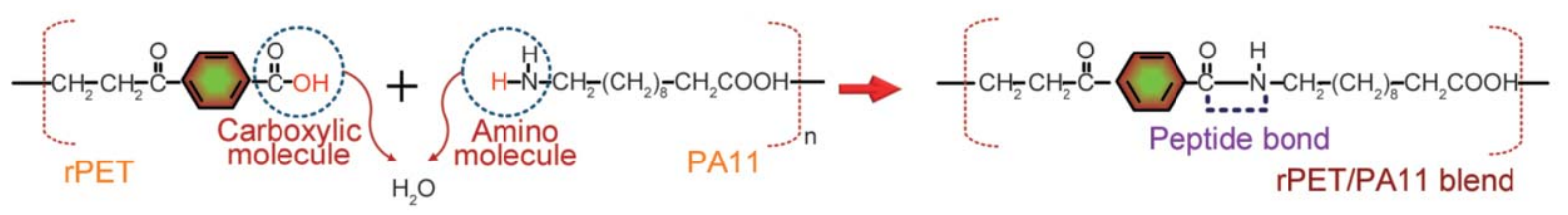

a)

Reaction mechanism without ADR 4468

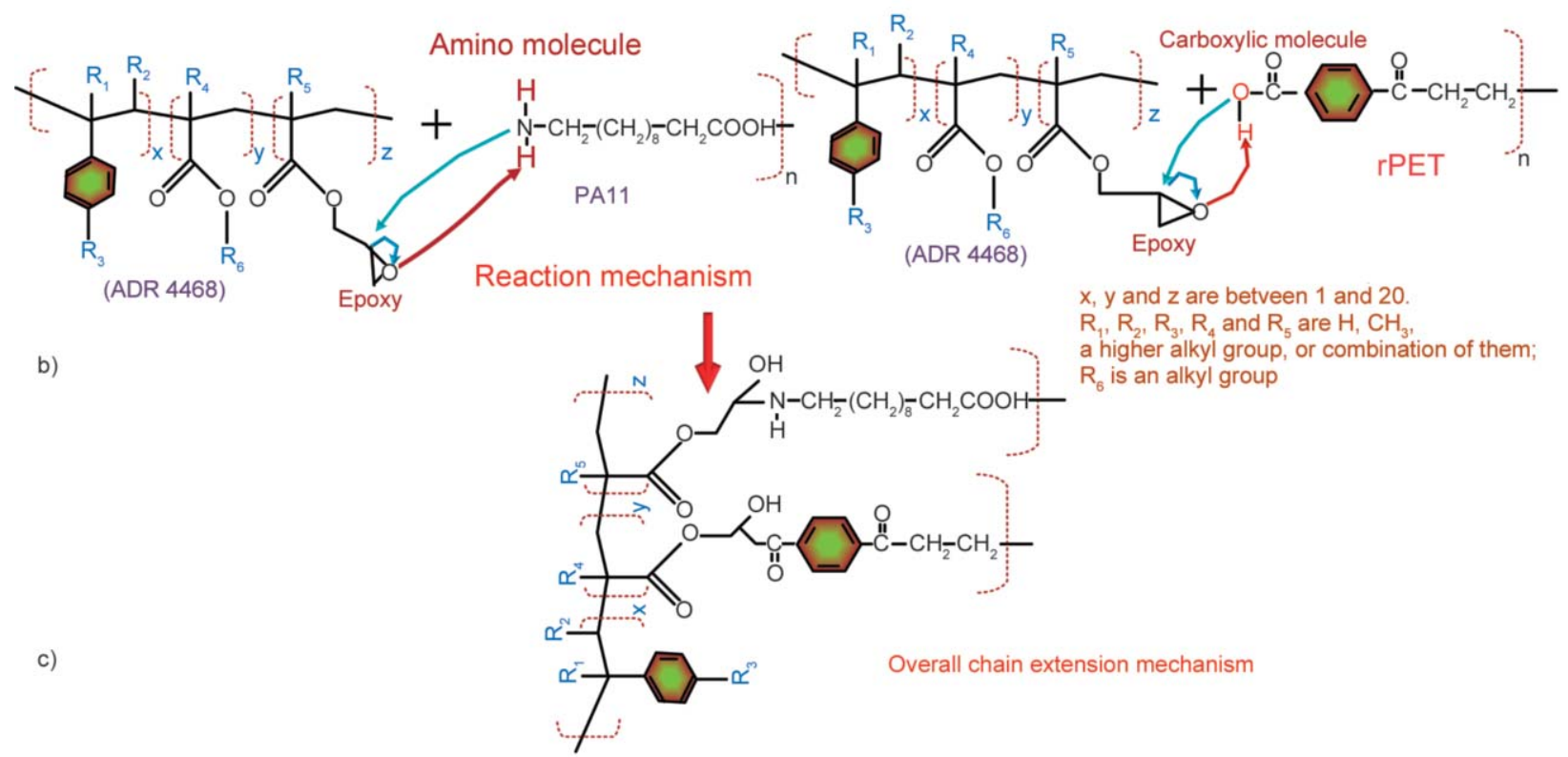

Figure 3. a) Reaction without Joncryl ${ }^{\circledR}$ ADR 4468 , b) reaction mechanism, c) overall chain extension mechanism.

with 2 phr of Joncryl ${ }^{\circledR}$ show decreased peak intensity, indicating the phenomenon of higher chain extension of blend rPET/PA11 in the presence of a 2 phr Joncryl ${ }^{\circledR}$. The proposed chain extension mechanism has been shown in Figure 3.

The reduction of absorbance peak at $3295.7 \mathrm{~cm}^{-1}$ of rPET/PA11/2 phr Joncryl ${ }^{\circledR}$ was compared with the peak of uncompatibilized $\mathrm{rPET} / \mathrm{PA} 11$ blend reduced carboxylic molecules of rPET and the amine end of PA11 due to the chain extension reaction with the epoxy group from Joncryl ${ }^{\circledR}$. Hynes et al. [28] reported the $\mathrm{CN}$ bond in the same FTIR spectra range. The rPET/PA11 C-NH bond has been confirmed by Khan et al. [24]. The epoxy group of Joncryl ${ }^{\circledR}$ with carboxylic group of PLA and the amine group of PA11 have been reported by Al-Itry et al. [29] and Rasselet et al. [30]. The increase of bondings with the broadening and decreased peak intensity is confirmed by Mohamed et al. [31]. The results show that melt processing has produced a polycondensation blend between rPET and PA11 polymer chains. The proposed chain mechanism has been shown in Figure 3.

The chemical structure of PET, PA11 and Joncryl ${ }^{\circledR}$ ADR was reported by Rosmmi et al. [23]. The mechanism and reaction of rPET with Joncryl ${ }^{\circledR}$, PA11 with Joncryl ${ }^{\circledR}$, and chain extension of rPET/PA11 with Joncryl ${ }^{\circledR}$ are shown in Figure 3. Figure 3a is showing the reaction mechanism of rPET and PA11 without the addition of compatibilizer Joncry ${ }^{\circledR}$. The carboxyl group of rPET reacts with an amino group of PA11, releasing a water molecule $\left(\mathrm{H}_{2} \mathrm{O}\right)$ and bonding through a peptide bond. However, with the addition of Joncry $1^{\circledR}$ in the blend, the reaction mechanism is showed in steps; firstly, the carboxylic end of rPET and amine end of PA11 interact with the epoxy group of Joncryl ${ }^{\circledR}$ to form bonds by exchanging the electrons between the epoxy group of ADR 4468 and then with the amine group of PA11 and epoxy group of ADR 4468 and carboxyl molecule of rPET as shown in Figure 3b, each separately. Finally, as shown in Figure 3c, rPET and PA11 are linked through the reactive epoxy group of Joncryl ${ }^{\circledR}$ ADR 4468. The reactions are nearly following the work done by Walha et al. [32] predicted for polylactic acid (PLA) and PA11 with Joncryl ${ }^{\circledR}$ compatibilizer. The average diameter of the dispersed particles versus the concentration of Joncryl ${ }^{\circledR}$ was mentioned in Figure $7 \mathrm{~b}$ by Walha et al. [32]. According to their findings, the average diameter of dispersed phase decreases with the increase of Joncryl ${ }^{\circledR}$ content; however, the maximum content used by them was $1 \mathrm{phr}$ of Joncryl ${ }^{\circledR}$. The decrease in diameter indicates that coalescence has been suppressed due to the epoxide's chemical reactivity with the blend's polymers. 
Furthermore, the same reaction mechanism has also been explained in detail by them.

\subsection{Morphology of $\mathrm{rPET} / \mathrm{PA} 11 /$ Joncryl $^{\circledR}$ blends}

Morphology of the blend is the key element that contributes to mechanical properties. Morphology of rPET/PA11/Joncryl ${ }^{\circledR}$ for all the blends fractured tensile samples were carried out through SEM. Figure 4 illustrates micrographs for rPET/PA11 having $80: 20 \mathrm{wt} \%$ ratio with $0,1,2,3$ and 4 phr of Joncryl ${ }^{\circledR}$ ADR 4468 at $4000 \times$ magnification. The samples of rPET/PA11 blends having 0 and 1 phr of Joncryl ${ }^{\circledR}$ blends display the morphology of dispersed white sphere PA11 particles in a continuous rPET matrix. For the blend without Joncryl ${ }^{\circledR}$, the PA11 particle is not a perfect sphere shape but an irregular particle shape. The elongated PA11 particles and few pullouts were observed due to the resistance to the tensile force applied during testing. The elongated particles show that rPET/PA11 has good interaction and adhesion at the ratio of 80:20. The effect of different rPET/PA11 ratios on the blend's morphology has been reported in our previous communication [24]. Upon Joncryl ${ }^{\circledR}$ addition (1 phr), the morphology changed. The PA11 particles become larger and perfect spheres in shape. The particles size observed in these specimens was in the range of $1.95-5.82 \mu \mathrm{m}$ compared to $0.62-5.9 \mu \mathrm{m}$ for the blend without Joncryl ${ }^{\circledR}$. The reactive epoxy group of Joncry $l^{\circledR}$ favours the amine group of PA11 then hydroxyl groups of rPET. It will cause the intermolecular interaction between the PA11 chain that can cause more chain entanglement and increase PA11 particle size. Even though the particle size is bigger and causes the pullout (Figure 3b) in the blend compared to the smaller particle size, the interaction imparted by Joncryl ${ }^{\circledR}$ dominated and increased the blend's mechanical properties compared to blend without Joncryl ${ }^{\circledR}$. However, the morphology observed for the rPET/PA11 blend having 2 phr of Joncryl ${ }^{\circledR}$ was surprising and unique, as shown in Figure 4c. SEM micrograph in Figure $4 \mathrm{c}$ for rPET/PA11 having 2 phr Joncryl ${ }^{\circledR}$ is showing the complete miscibility and giving the sign of a new compatible blend formation. The ductile matrix tearing on the tensile fractured surface indicates the blend increased ductility. The miscible blend also reveals the high tensile strength and toughness of the blend developed with $2 \mathrm{phr}$ of Joncry ${ }^{\circledR}$ compared to other ratios. This might be due to the optimum amount of Joncryl ${ }^{\circledR}$ used for the 80:20 proportion of rPET/ PA11. The active groups fully consume the reactive groups of Joncryl ${ }^{\circledR}$ in rPET and PA11 in the chain extension reaction. Figure $4 \mathrm{c}$ depicts the complete cup and cone structure for tensile fractured specimens. A cup and cone fracture is a form of failure that occurs when a ductile polymer or blend is subjected to a uniaxial force. It is the splitting of a body into two separate parts as a result of high tensile tension. The resulting shapes at the ends of the broken pieces after a failure give rise to the name of this mode of fracture.

The miscible blends were also observed at higher Joncryl ${ }^{\mathbb{R}}$ content ( 3 and $4 \mathrm{phr}$ ) (Figure $4 \mathrm{~d}$ and $4 \mathrm{e}$ ). However, the excess of Joncryl ${ }^{\mathbb{R}}$ acts as the excessive $\mathrm{C}-\mathrm{NH}$ and $\mathrm{OH}$ linking through the epoxy group in the blends that make the blend stiff the blend materials at higher compatibilizer content, thus reducing the percentage tensile strain and impact strength of the blends. However, the tensile and impact strength are still dominated by the interaction imparted by Joncryl ${ }^{\mathbb{R}}$ in the blend compared to the uncompatibilized rPET/PA11 blend. The 2 phr Joncryl ${ }^{\circledR}$ acts as the chain extender and compatibilizer in rPET/ PA11 blend, thus enhancing the rPET/PA11 blends' mechanical properties. The overall chain extension mechanism has been proposed in Figure 3c.

\subsection{The mechanical properties of the rPET/PA11/Joncryl ${ }^{\circledR}$ blends}

Figure 5 illustrates the tensile strength, percentage of tensile strain, Young's modulus, and the comparison of Young's modulus with the impact strength of all rPET/PA11/Joncryl ${ }^{\circledR}$ blends. Initially, the tensile strength of rPET/PA11(80:20) was $26.86 \mathrm{MPa}$, which was then enhanced to $43.8,46.24,47.92$, and $49.94 \mathrm{MPa}$ with the incorporation of 1, 2, 3, and $4 \mathrm{phr}$ of Joncryl ${ }^{\circledR}$, respectively as shown in Figure $4 \mathrm{a}$. The tensile strength is showing an increasing trend with the addition of Joncryl ${ }^{\circledR}$. The strong interaction between the epoxy group of Joncryl ${ }^{\mathbb{R}}$ with the amine group of PA11 and the hydroxyl group of rPET dominated the blend's tensile strength. However, the percentage of tensile strain is unique and gives a breakthrough for the blend of rPET/PA11 having 2 phr of Joncryl ${ }^{\circledR}$. It was $196 \%$ higher for this ratio as compared to all other ratios. The optimum compatibilization imparted by Joncryl ${ }^{\circledR}$ at this ratio displayed the optimum strain of the blend materials. 

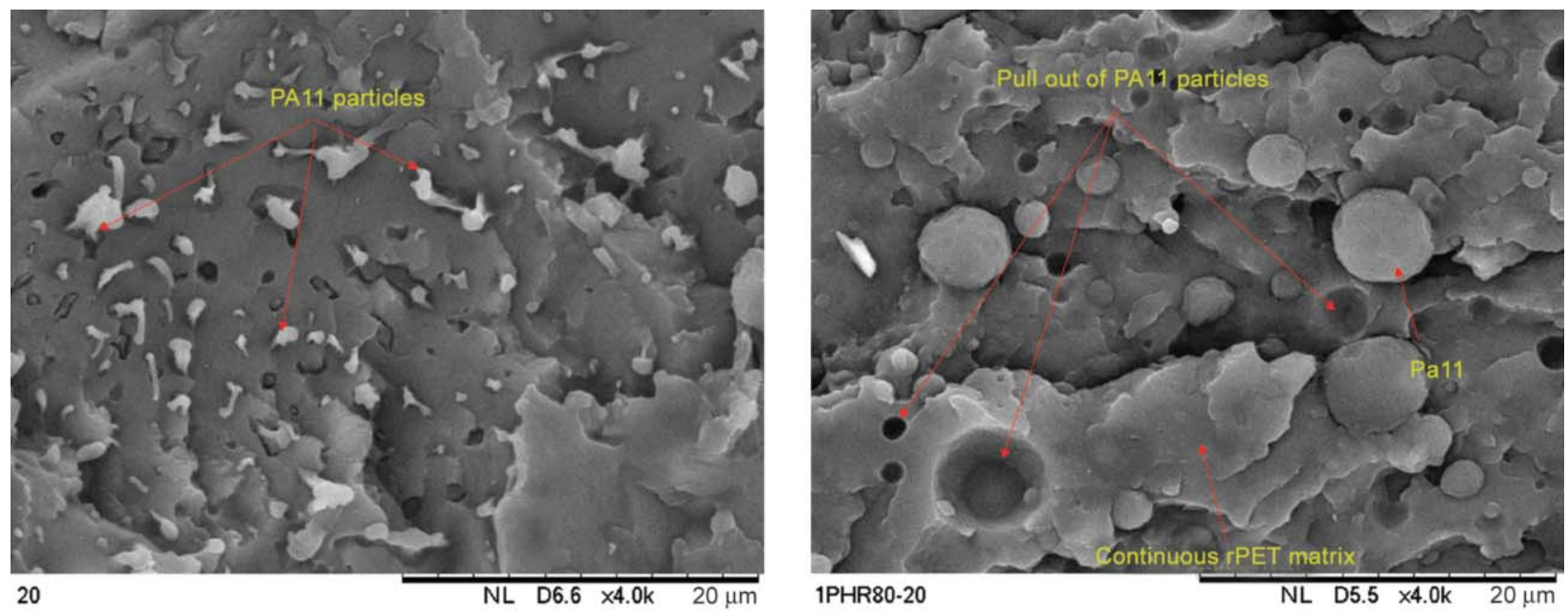

a)

b)

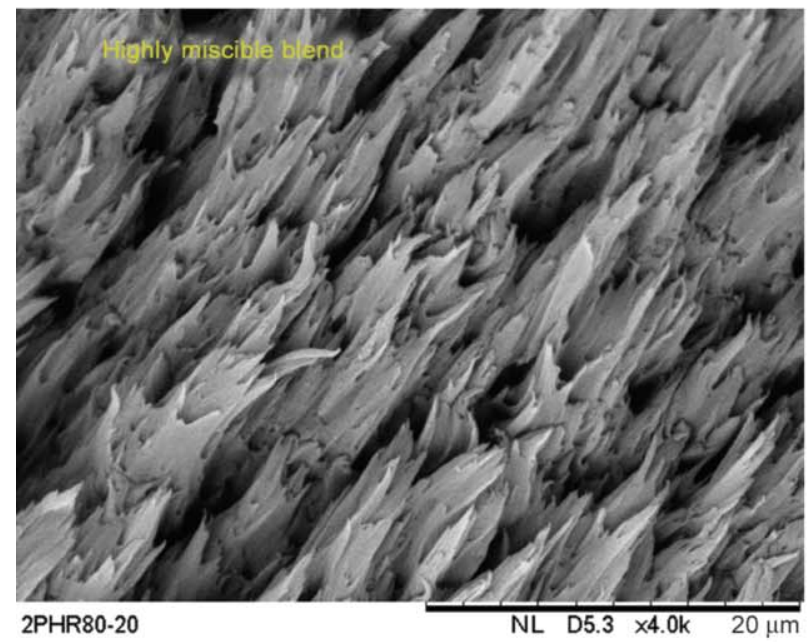

c)

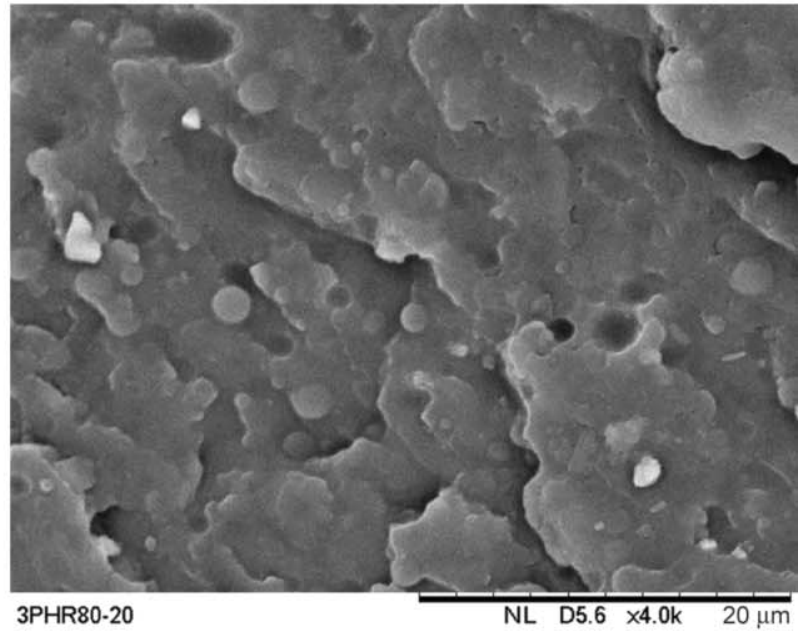

d)

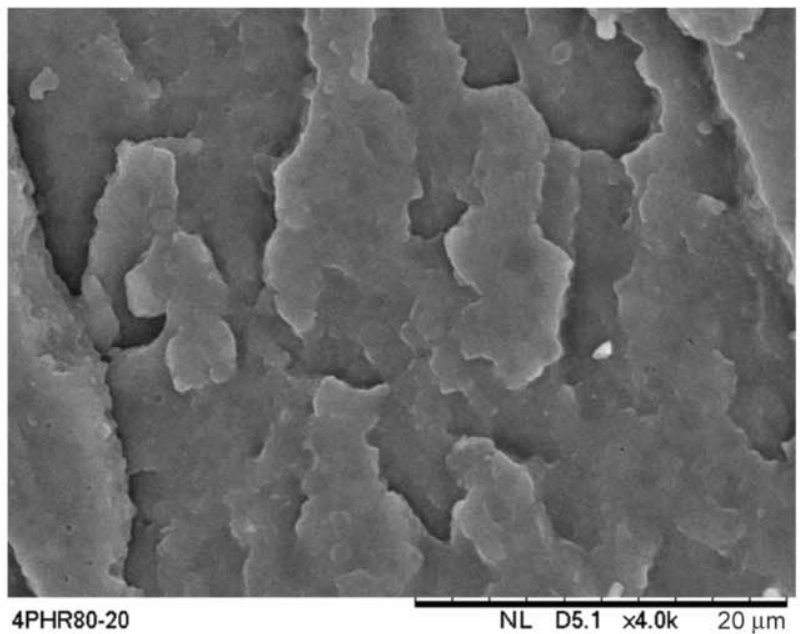

e)

Figure 4. SEM morphology of rPET/PA11/Joncryl ${ }^{\circledR}$ blends. a) rPET/PA11 (80/20) 0 phr Joncryl ${ }^{\circledR}$. b) rPET/PA11 (80/20) 1 phr Joncryl ${ }^{\circledR}$. c) rPET/PA11 (80/20) 2 phr Joncryl ${ }^{\circledR}$. d) rPET/PA11 (80/20) 3 phr Joncryl ${ }^{\circledR}$. e) rPET/PA11 $(80 / 20)$ 4 phr Joncryl ${ }^{\circledR}$.

Interestingly Young's modulus of this blend was also found highest among all other ratios, as shown in Figure 5c. Young's modulus of uncompatibilized blends was found $503.75 \mathrm{MPa}$, showing an upsurge to $969.25 \mathrm{MPa}$ for rPET/PA11/Joncryl ${ }^{\circledR}$ having $2 \mathrm{phr}$ of Joncryl ${ }^{\circledR}$ while a further increase of Joncryl ${ }^{\circledR}$ decreased Young's modulus. This was due to the excessive linking and entanglements of the blend 
chains imparted by the excess Joncryl ${ }^{\circledR}$. Figure $5 d$ represents the relation between stiffness and toughness (Young's modulus vs. Impact strength) of the blends. The rPET/PA11 blend having $2 \mathrm{phr}$ of Joncryl ${ }^{\circledR}$ was the most balanced blend in stiffness and toughness properties. These are the critical properties that determine the application of the blend materials. The results obtained were consistent with the Fornes and Paul [21], who reported the stress-strain difference behaviour in the nylon group.

The superior properties of the newly developed rPET/PA11 blend having 2 phr of Joncry $l^{\circledR}$ have also been confirmed by the FTIR and morphological examination. The increased tensile strength values were more significant than $\mathrm{rPET} / \mathrm{HDPE}$ blends reported by Shahrajabian and Sadegihan [10]. This was due to polar and polar heads' existence to create an interface or bond between $\mathrm{rPET} / \mathrm{PA} 11$ polymers, as depicted in Figure 3 [33].

Shahrajabian and Sadegihan [10] also observed an increase in tensile strength of rPET with the addition of HDPE, alumina nanoparticles, and compatibilizers, and their uppermost value was $33.5 \pm 2.3 \mathrm{MPa}$. However, a higher tensile strength (47.92 MPa) was

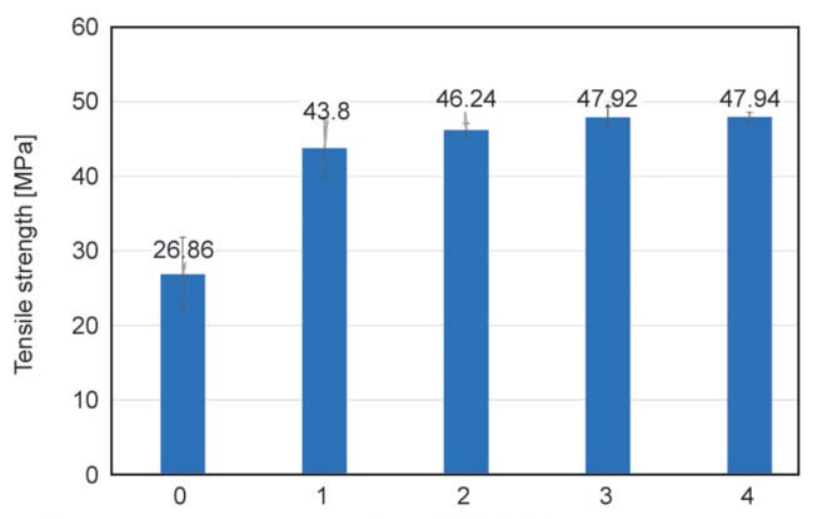

a)

Joncryl $^{\oplus 4} 4468$ [phr]

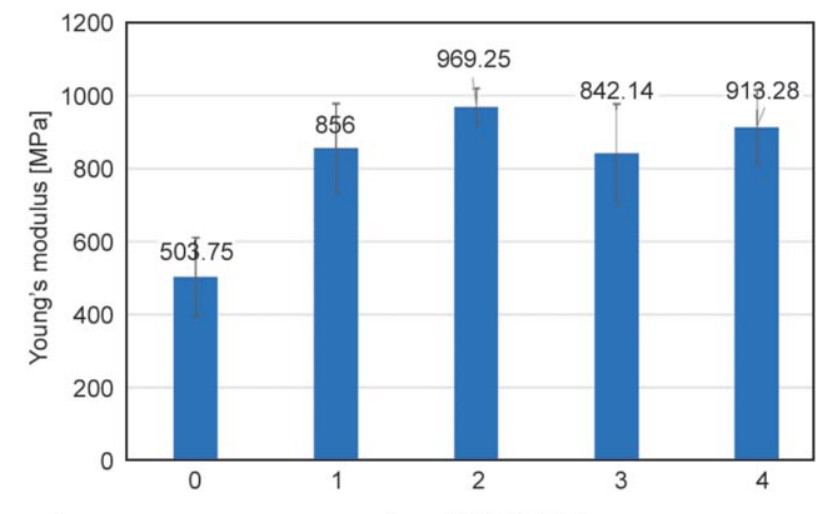

c)

Joncryl $\left.\right|^{\oplus} 4468[\mathrm{phr}]$ attained in this work, deprived of nanoparticles. The strain percentage is also tremendously increased by $196 \%$ without sacrificing the tensile strength and Young's modulus.

Figures $6 \mathrm{a}$ and $6 \mathrm{~b}$ represent the flexural strength and modulus of rPET/PA11 (80:20) for all five blends having $0,1,2,3$ and 4 phr of Joncryl ${ }^{\circledR}$. The flexural strength of uncompatibilized $\mathrm{rPET} / \mathrm{PA} 11$ is recorded at $36.68 \mathrm{MPa}$ and increased to $86.98 \mathrm{MPa}$ at $4 \mathrm{phr}$ of Joncry ${ }^{\circledR}$. Joncryl ${ }^{\circledR}$ was effective in enhancing the interaction, thus increasing the compatibility between the rPET and PA11 matrix. However, the Flexural modulus showed no significant difference, and the highest (2530 MPa) flexural modulus was recorded for the blend having $2 \mathrm{phr}$ Joncryl ${ }^{\circledR}$. This was due to blend highest miscibility at $2 \mathrm{phr}$ of Joncryl ${ }^{\circledR}$ shown in morphological results Figure 4c.

\subsection{Impact testing}

Figure 7 shows the impact strength of rPET/PA11/ Joncry $1{ }^{\circledR}$ blends having Joncryl ${ }^{\circledR}$ of $0,1,2,3$ and $4 \mathrm{phr}$. The impact strength of uncompatibilized rPET/ PA11 blends is found to be $147.12 \mathrm{~J} / \mathrm{m}$. The impact strength of rPET/PA11 is increased to 257.32, 667.68,

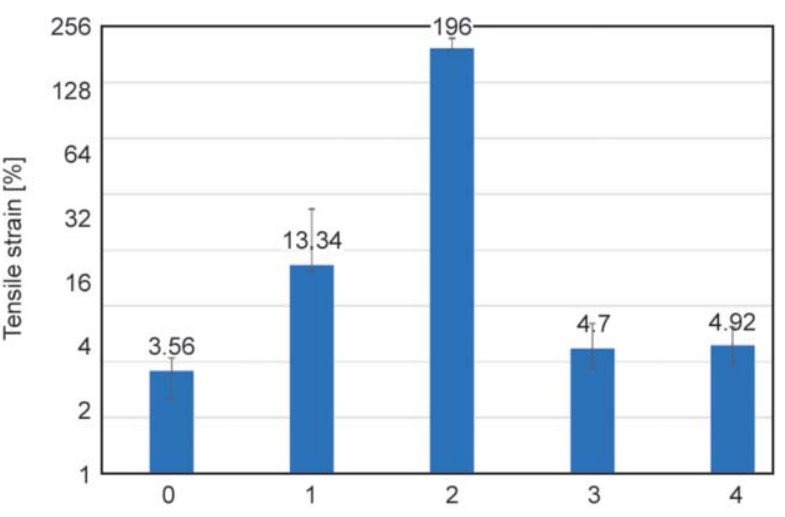

b)

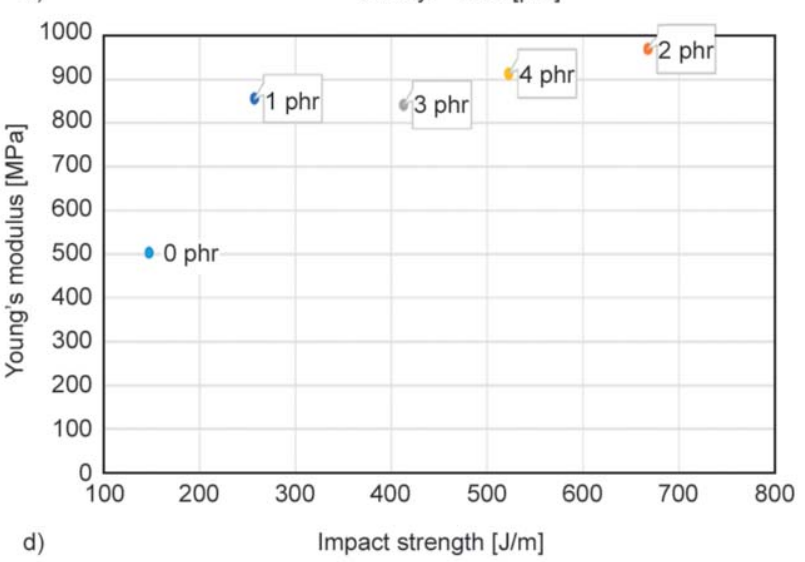

Figure 5. Represents a) tensile strength, b) tensile strain, c) Young's modulus, d) Young's modulus vs. impact strength of $\mathrm{rPET} / \mathrm{PA} 11 /$ Joncryl $^{\circledR}$ at various loading. 

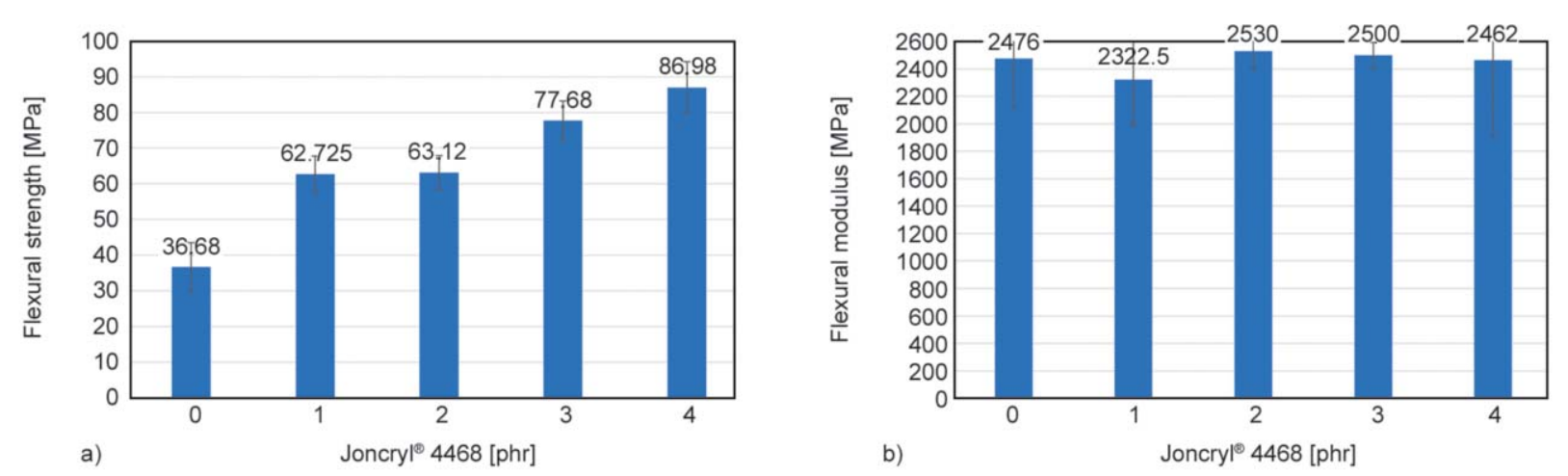

Figure 6. a) Flexural strength and b) flexural modulus of rPET/PA11/Joncryl ${ }^{\circledR}$ blends.

412.34, and $522.40 \mathrm{~J} / \mathrm{m}$ with the incorporation of a compatibilizer Joncryl ${ }^{\circledR}$ of $1,2,3$ and $4 \mathrm{phr}$, respectively. The impact strength of all the blends was enhanced with the addition of Joncryl ${ }^{\circledR}$. The improved interaction and compatibility imparted by Joncryl ${ }^{\mathbb{R}}$ are key factors that influence the impact properties of the blend, especially at $2 \mathrm{wt} \%$ Joncry ${ }^{\circledR}$. Mechanical properties of rPET/PA11/Joncry ${ }^{\circledR}$ increased due to the formation of Joncryl ${ }^{\mathbb{B}}$ based $(\mathrm{NCH})$ reaction and ester linkage at the interface, as shown in Figure 3a-3c), thus increasing molecular weight and properties. rPET/PA11 (80:20) having 2 phr of Joncryl ${ }^{\circledR}$ is giving the utmost balanced properties. The reason for the supervisor properties of rPET/ PA11 at 2 phr of Joncry ${ }^{\mathbb{B}}$ is the complete miscibility of polymers at this ratio, as confirmed by the reactions and morphological results in Figure 3 and Figure 4.

\section{Conclusions}

The work was commenced to recycle the PET in a higher ratio instead of going to the landfill sites. Therefore, a new blend was developed having rPET/ PA11 (80:20) ratios in the presence of a compatibilizer,

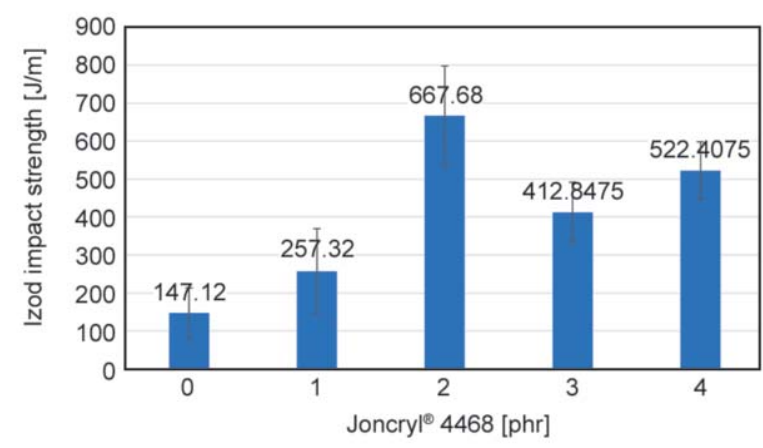

Figure 7. Impact strength of rPET/PA11/Joncryl ${ }^{\circledR}$ blends.
Joncryl ${ }^{\circledR}$ ADR 4468 , for the first time. It is a great success to recycle $80 \mathrm{wt} \%$ of $\mathrm{rPET}$ in a ratio having utmost properties. The results are exposing the distinctive and innovative properties of this blend. Tensile strength, percentage tensile strain, and Young's modulus of the polymer blend were enhanced significantly with the addition of Joncryl ${ }^{\circledR}$. The rPET/ PA11 (80:20) with 2 phr Joncryl ${ }^{\circledR}$ blend of rPET has given the outburst to improve mechanical properties. Tensile strength and percentage strain were improved higher than 100 and $196 \%$, respectively. Tensile modulus of rPET/PA11 was improved from 503.75 to $969.25 \mathrm{MPa}$ at $2 \mathrm{phr}$ of Joncryl ${ }^{\circledR}$. Flexural strength and flexural modulus of rPET/PA11 also showed considerable upsurge at all proportions with the addition of Joncryl ${ }^{\circledR}$. A rise in flexural strength of more than $100 \%$ was recorded. The impact strength of rPET/PA11 (80:20) with 0 phr of Joncryl ${ }^{\circledR}$ was $147.12 \mathrm{~J} / \mathrm{m}$. However, it was increased to $667.68 \mathrm{~J} / \mathrm{m}$ with the addition of $2 \mathrm{phr}$ Joncryl ${ }^{\circledR}$ compatibilizer. Overall, rPET/PA11(80:20) with 2 phr Joncryl ${ }^{\circledR}$ demonstrated the ultimate mechanical properties. One of the most important findings is the balance properties between stiffness and toughness given by this formulation of the rPET/PA11 blends that can manifest the better and wide applications of the blend materials. The preeminence of this ratio was verified via SEM and FTIR results.

\section{Acknowledgements}

We wish to express our gratitude to the Ministry of Education Malaysia (MOE) and Universiti Teknologi Malaysia (UTM) for financial support under Fundamental research grant FRGS/1/2019/TK05/UTM/02/17 (5F185) and GUP 05G85, 05G86, 08G50, 05G52. 


\section{References}

[1] Lin X., Qian Q., Xiao L., Chen Q., Huang Q., Zhang H.: Influence of reactive compatibilizer on the morphology, rheological, and mechanical properties of recycled poly(ethylene terephthalate)/polyamide 6 blends. Journal of Macromolecular Sciences Part B: Physics, 53, 1543-1552 (2014).

https://doi.org/10.1080/00222348.2014.946840

[2] Khan Z. I., Arsad A., Mohamad Z., Habib U., Zaini M. A. A.: Comparative study on the enhancement of thermo-mechanical properties of carbon fiber and glass fiber reinforced epoxy composites. Materials Today: Proceedings, 39, 956-958 (2020).

https://doi.org/10.1016/j.matpr.2020.04.223

[3] Abdullah N. A. S., Mohamad Z., Khan Z. I., Jusoh M., Zakaria Z. Y., Ngadi N.: Alginate based sustainable films and composites for packaging: A review. Chemical Engineering Transactions, 83, 271-276 (2021). https://doi.org/10.3303/CET2183046

[4] Li S., Wang W., Yu L., Xia Z., Li X.: Influence of different compatibilizers on the morphology and properties of PA6/PET/glass fiber composites. Journal of Applied Polymer Science, 135, 46429/1-46429/8 (2018). https://doi.org/10.1002/app.46429

[5] Sangroniz L., Ruiz J. L., Sangroniz A., Fernández M., Etxeberria A., Müller A. J., Santamaria A.: Polyethylene terephthalate/low density polyethylene/titanium dioxide blend nanocomposites: Morphology, crystallinity, rheology, and transport properties. Journal of Applied Polymer Science, 136, 46986/1-46986/10 (2019). https://doi.org/10.1002/app.46986

[6] Guo Z., Lindqvist K., de la Motte H.: An efficient recycling process of glycolysis of PET in the presence of a sustainable nanocatalyst. Journal of Applied Polymer Science, 135, 46285/1-46285/6 (2018). https://doi.org/10.1002/app.46285

[7] Malik N., Kumar P., Shrivastava S., Ghosh S. B.: An overview on PET waste recycling for application in packaging. International Journal of Plastics Technology, 21, 1-24 (2017). https://doi.org/10.1007/s12588-016-9164-1

[8] Al-Sabagh A. M., Yehia F. Z., Eshaq G., Rabie A. M., ElMetwally A. E.: Greener routes for recycling of polyethylene terephthalate. Egyptian Journal of Petroleum, 25, 53-64 (2015). https://doi.org/10.1016/j.ejpe.2015.03.001

[9] Geyer B., Lorenz G., Kandelbauer A.: Recycling of poly(ethylene terephthalate) - A review focusing on chemical methods. Express Polymer Letters, 10, 559586 (2016).

https://doi.org/10.3144/expresspolymlett.2016.53

[10] Shahrajabian H., Sadeghian F.: The investigation of alumina nanoparticles' effects on the mechanical and thermal properties of HDPE/rPET/MAPE blends. International Nano Letters, 9, 213-219 (2019). https://doi.org/10.1007/s40089-019-0273-7
[11] Taghavi S. K., Shahrajabian H., Hosseini H. M.: Detailed comparison of compatibilizers MAPE and SEBS$g$-MA on the mechanical/thermal properties, and morphology in ternary blend of recycled PET/HDPE/ MAPE and recycled PET/HDPE/SEBS- $g$-MA. Journal of Elastomers and Plastics, 50, 13-35 (2018). https://doi.org/10.1177/0095244317698738

[12] Ávila A. F., Duarte M. V.: A mechanical analysis on recycled PET/HDPE composites. Polymer Degradation and Stability, 80, 373-382 (2003). https://doi.org/10.1016/S0141-3910(03)00025-9

[13] Montava-Jorda S., Lascano D., Quiles-Carrillo L., Montanes N., Boronat T., Martinez-Sanz A. V., Ferrandiz-Bou S., Torres-Giner S.: Mechanical recycling of partially bio-based and recycled polyethylene terephthalate blends by reactive extrusion with poly (styrene-co-glycidyl methacrylate). Polymers, 12, 174194 (2020). https://doi.org/10.3390/polym12010174

[14] Inuwa I. M., Razak N. C. A., Arjmandi R., Hassan A.: Effects of halloysite nanotubes on the mechanical, thermal, and flammability properties of PP-g-MAH compatibilized polyethylene terephthalate/polypropylene nanocomposites. Polymer Composites, 39, E1554E1564 (2018).

https://doi.org/10.1002/pc. 24470

[15] Louzi V. C., de Carvalho Campos J. S.: Corona treatment applied to synthetic polymeric monofilaments (PP, PET, and PA-6). Surfaces and Interfaces, 14, 98107 (2019). https://doi.org/10.1016/j.surfin.2018.12.005

[16] Calcagno C. I. W., Mariani C. M., Teixeira S. R., Mauler R. S.: The role of the MMT on the morphology and mechanical properties of the PP/PET blends. Composites Science and Technology, 68, 2193-2200 (2008). https://doi.org/10.1016/j.compscitech.2008.03.012

[17] Mishra R. K., Mishra P., Verma K., Joseph K.: Manipulation of thermo-mechanical, morphological and electrical properties of PP/PET polymer blend using MWCNT as nano compatibilizer: A comprehensive study of hybrid nanocomposites. Vacuum, 157, 433441 (2018).

https://doi.org/10.1016/j.vacuum.2018.08.061

[18] Krumova M., Fakirov S., Baltá Calleja F. J., Evstatiev M.: Structure development in PET/PA6 microfibrillarreinforced composites as revealed by revealed by microhardness. Journal of Materials Science, 33, 2857-2868 (1998). https://doi.org/10.1023/A:1017594021634

[19] Lu C., Gao X-P., Yao D-H., Cao C-L., Luo Y.: Improving flame retardancy of linear low-density polyethylene/nylon 6 blends via controlling localization of clay and intumescent flame-retardant. Polymer Degradation and Stability, 153, 75-87 (2018).

https://doi.org/10.1016/j.polymdegradstab.2018.04.022 
[20] Barkoula N-M., Peijs T., Schimanski T., Loos J.: Processing of single polymer composites using the concept of constrained fibers. Polymer Composites, 26, 114120 (2005).

https://doi.org/10.1002/pc.20082

[21] Fornes T. D., Paul D. R.: Structure and properties of nanocomposites based on nylon-11 and -12 compared with those based on nylon-6. Macromolecules, 37, 7698 7709 (2004).

https://doi.org/10.1021/ma048757o

[22] Latko P., Kolbuk D., Kozera R., Boczkowska A.: Microstructural characterization and mechanical properties of PA11 nanocomposite fibers. Journal of Materials Engineering and Performance, 25, 68-75 (2016). https://doi.org/10.1007/s11665-015-1817-2

[23] Rosmmi N. H. M., Khan Z. I., Mohamad Z., Majid R. A., Othman N., Man S. H. C., Karim K. J. A.: Impact strength and morphology of sustainably sourced recycling polyethylene terephthalate blends. Chemical Engineering Transactions, 83, 265-270 (2021). https://doi.org/10.3303/CET2183045

[24] Khan Z. I., Mohamad Z. B., Rahmat A. R. B., Habib U., Abdullah N. A. S. B.: A novel recycled polyethylene terephthalate/polyamide 11 (rPET/PA11) thermoplastic blend. Progress in Rubber, Plastics and Recycling Technology, in press (2021)

https://doi.org/10.1177/14777606211001074

[25] Samios C. K., Kalfoglou N. K.: Compatibilization of poly(ethylene terephthalate)/polyamide- 6 alloys: Mechanical, thermal and morphological characterization. Polymer, 40, 4811-4819 (1999). https://doi.org/10.1016/S0032-3861(98)00709-5

[26] Evstatiev M., Fakirov S., Schultz J. M., Friedrich K.: In situ fibrillar reinforced PET/PA-6/PA-66 blend. Polymer Engineering and Science, 41, 192-204 (2001). https://doi.org/10.1002/pen.10721
[27] Daneshvar M., Masoomi M.: Synthesis and application of MDPE- $g$-GMA as reactive compatibilizer in blends of MDPE/PET and MDPE/PA6. Journal of Applied Polymer Science, 124, 2048-2054 (2012).

https://doi.org/10.1002/app.35235

[28] Hynes A., Scott D. A., Man A., Singer D. L., Sowa M. G., Liu K. Z.: Molecular mapping of periodontal tissues using infrared microspectroscopy. BMC Medical Imaging, 5, 1-10 (2005). https://doi.org/10.1186/1471-2342-5-2

[29] Al-Itry R., Lamnawar K., Maazouz A.: Improvement of thermal stability, rheological and mechanical properties of PLA, PBAT and their blends by reactive extrusion with functionalized epoxy. Polymer Degradation and Stability, 97, 1898-1914 (2012). https://doi.org/10.1016/j.polymdegradstab.2012.06.028

[30] Rasselet D., Caro-Bretelle A. S., Taguet A., LopezCuesta J. M.: Reactive compatibilization of PLA/PA11 blends and their application in additive manufacturing. Materials, 12, 485-505 (2019). https://doi.org/10.3390/ma12030485

[31] Mohamed M. A., Jaafar J., Ismail A. F., Othman M. H. D., Rahman M. A.: Fourier transform infrared (FTIR) spectroscopy. in 'Membrane characterization' (eds.: Hilal N., Ismail A. F., Matsuura T., Oatley-Radcliffe D.) Elsevier, Johor Bahru, Vol 1, 3-29 (2017). https://doi.org/10.1016/B978-0-444-63776-5.00001-2

[32] Walha F., Lamnawar K., Maazouz A., Jaziri M.: Rheological, morphological and mechanical studies of sustainably sourced polymer blends based on poly(lactic acid) and polyamide 11 . Polymers, 8, 61-84 (2016). https://doi.org/10.3390/polym8030061

[33] Oliveux G., Dandy L. O., Leeke G. A.: Current status of recycling of fibre reinforced polymers: Review of technologies, reuse and resulting properties. Progress in Materials Science, 72, 61-99 (2015).

https://doi.org/10.1016/j.pmatsci.2015.01.004 